\title{
Astronomers told to cut it out
}

\section{WASHINGTON DC}

There's no point in complaining: some US ground-based telescopes almost certainly must close if the country's astronomy spending is to be brought under control.

That was the bleak message delivered to a room of anxious astronomers on 10 January by officials of the National Science Foundation (NSF) during the American Astronomical Society's annual meeting in Washington DC. Faced with flat budgets and growing expenditures, the foundation has asked a panel of 13 senior scientists to find $\$ 30$ million in savings out of the astronomy division's \$195-million annual budget by any means necessary.

"The problem is huge,"

"I say we complain, and complain bitterly."

including the Gemini, Kitt Peak, Arecibo and National Solar observatories, and the National Astronomy and Ionosphere Center.

In addition to these telescopes, the NSF is planning several costly, next-generation projects. It is putting nearly $\$ 50$ million a year towards constructing the Atacama Large Millimeter Array (ALMA), an international radio telescope set to be completed in 2012. And it recently committed $\$ 14$ million to developing the Large Synoptic Survey Telescope, a project to digitally record much of the night sky.

Money is allocated separately for the construction of these and other facilities, but Van Citters says it is unclear how the agency will operate them once they are Wayne Van Citters, director of the foundation's astronomy division, told the assembled scientists. "We're rapidly outstripping our ability to operate the things that we are building."

The agency is the main government supporter of ground-based astronomy in the United States. It operates several major facilities, of the Kavli Institute for Particle Astrophysics and Cosmology in Stanford, California, chairs the panel that will recommend where the cuts should fall. The Washingon meeting was the last of seven held in an attempt to placate astronomers around the country since the panel was announced in August (see Nature 436, 616; 2005).

Blandford says the panel will consider the scientific value of the various facilities, as well as their training capabilities, decommissioning costs and overlap with other observatories. Scientific value, in particular, is notoriously difficult to measure quantitatively - an attempt by one astronomer at the conference demonstrates as much (see "Which sites get cited?, opposite). "There are no easy targets," says Blandford. "We are trying very hard to make this a responsible process."

It was clear that many of the 200 or so astronomers in the room were not convinced. "If we go through with the cuts then major facilities will disappear," warns Jeffrey Linsky, an astronomer at the Joint Institute for Laboratory

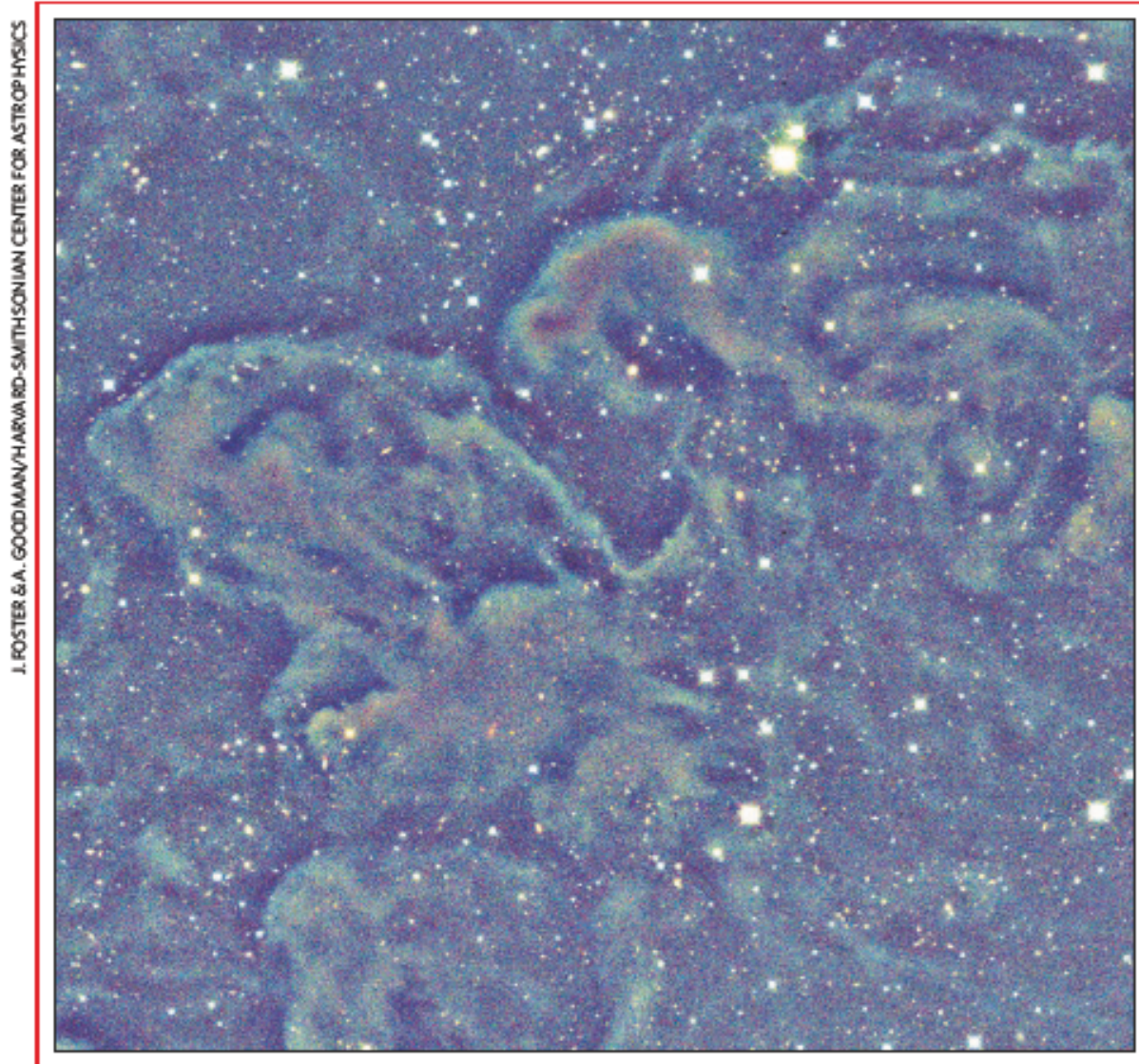

\section{SNAPSHOT Cloudshine is a stellar snap for Harvard duo}

These ghostly swirls are the first images of gas clouds reflecting starlight. Lying more than 1,000 light years away, they are part of the Perseus Molecular Cloud, a region where new stars form. Usually, suchclouds appear in as tronomical images merely as dark regions where light from more distants tars is blocked. Thermal emission from the gas and dustcan often be detected by radio telescopes, but directly reflected starlight 'cloudshine' - is normally too dim to see.

Jonathan Foster and Alyssa Goodman of the Harvard-Smithsonian Center for Astrophysics in Cambridge, Massachusetts, cap tured these false-colour images of the Perseus complex using the new OMEGA 2000 camera at Calar Alto Observatory in southern Spain (J. B. Foster and A. A. Goodman Astrophys. J. Lett. 636, L105-L108; 2006). They say that scattered light alone can explain the images, and that the near-infrared cloudshine could even be used to probe the threedimensional structure of molecular clouds. 


\section{NIH urged to enforce its public-access policy}

The US National Institutes of Health should require researchers to participate in its public-access policy rather than keep it voluntary, says the board of regents of the National Library of Medicine.

The policy requests all NIH-funded investigators to submit their peer-reviewed papers to the free PubMed Central database within one year of publication. In part, this is meant to help the public to access the results of federally funded research. But since the policy was implemented in May 2005 , fewer than $4 \%$ of eligible articles have been added, the board reports.

Lack of awareness or technical difficulties don't seem to be the problem, as the NIH has repeatedly encouraged researchers and publishers to submit their papers. The board expressed its opinion in an 8 February letter to NIH director Elias Zerhouni.

\section{Japan rejects Korean offer to discuss kidnap case}

Japan last week rejected a North Korean proposal to have genetics experts from both countries discuss the DNA analysis of some controversial human remains.

The rejection came at the end of bilateral talks in Beijing, during which Japan failed to make progress in finding out what happened to eight citizens kidnapped during the 1970s and 1980s. North Korea says the remains at the centre of the case are those of the woman Megumi Yokota. Japan said DNA tests show the remains belong to someone else, and demanded to know Yokota's whereabouts.

Last year, Tomio Yoshii, the scientist who carried out the tests, admitted that they were not conclusive (see Nature 433, 445; 2005). Yoshii, a DNA expert with the Tokyo metropolitan police, has not since responded to requests for confirmation from either journalists or politicians.

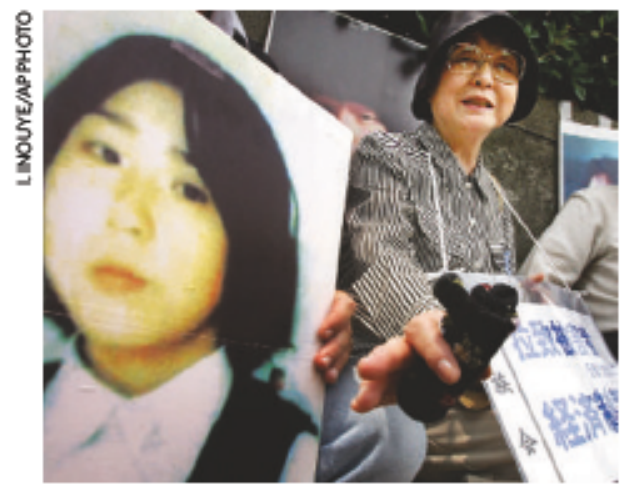

Missing: the family of Megumi Yokota call for Japanese sanctions against Nor th Korea
Plight of polar bears might force US action on climate

Prompted by lawsuits from environmental groups, the US government is considering putting polar bears on its list of threatened species. Activists hope such a listing will force the government to take action on climatechange.

Mostanimals protected by the Endangered Species Act are declining in numbers because humans are taking over their habitats. But themain threat to the bears is thought by many to be climate change, as rising temperatures melt the Arctic sea ice under their paws.

Once a species is listed, agencies are prohibited from taking any action that would jeop ardize it. Kassie Siegel, director of the climate programme at the environmental

\section{Patent office lets army alter description of weapons}

The US Army is deleting what it claims was a mistaken reference to chemical and biological weapons in a patent application.

In 2003, the army was issued a patent on a grenade that it said could be packed with various payloads, including chemical and biological agents (see Nature 423, 789; 2003). Critics were alarmed because international treaties and federal law ban the US government from making and using biological and chemical weapons.

At the time, the army said it had no intention of making such weapons, and asked the US patent office to delete the reference to these agents from the patent. Last February, the patent office refused, but it has now relented.

Critics remain concerned. "Changing the patent doesn't change the weapon," says Edward Hammond of the Sunshine Project, an international body that works to stop the use of biological weapons.

\section{US fails to make the grade on tackling ocean issues}

The Joint Ocean Commission Initiative has given the United States a D + on its efforts to combat problems facing the oceans, such as pollution and overfishing.

Suggestions from the US Commission on Ocean Policy and the Pew Oceans Commission prompted the Bush administration in 2004 to release an ocean action plan. The new report card suggests that little progress has been made in six areas from fisheries management to funding and education.

A White House spokeswoman, Michele St Martin, says that she expects higher marks

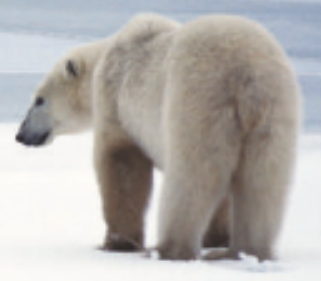

group Center for Biological Diversity, says she takes this to mean that the US government must control emissions of heat-trapping carbon dioxide more effectively. "We believe it is a very solid legal argument," Siegel says.

On 9 February, the USFish and Wildlife Service opened a 60-day period for public comments on whether to list the bear.

when future projects, such as reauthorizing a national fisheries conservation act, get under way.

\section{Methane deposits not to blame for sudden warming}

New data from a Greenland ice core have dealt what could be a blow to the idea that methane escaping from the seabed can drive rapid dimate changes.

Methane, a strong greenhouse gas, is buried in some sea-floor sediments in a crystal called methane clathrate. A release of trillions of tonnes of methane from clathrates, for example, is thought to have triggered a temperature jump some 55 million years ago at the Palaeocene/Eocene boundary. Other rapid warming events have also been attributed to methane releases.

Now Todd Sowers, an Earth scientist at Pennsylvania State University, has measured the hydrogen isotopes of atmospheric methane from three warming episodes, $38,000,14,500$ and 11,500 years ago. Methane from clathrates contains more of the heavy form of hydrogen than methane from land-based sources. Sowers found no evidence for increased amounts of methane from clathrates in these periods (T. Sowers Science 311, 838-840; 2006).

“This means that seafloor methane reservoirs must have been stable at these times, or at least that no significant amounts of methane escaped the ocean," Sowers says.

Correction

In our story "Cloudshine is a stellar snap for Harvard duo" (Nature 439, 250; 2006), we incorrectly presented an image from the cited paper as the first picture of cloudshine. Similar images have been taken in the past at optical and other wavelengths. 